\title{
Primary neurogenic orthostatic hypotension
}

\author{
R. C. Hughes, N. E. F. CARTLIDGe, AND P. MillaC \\ From the Departments of Neurology, The Royal Victoria Infirmary, Newcastle upon Tyne, and The Derbyshire \\ Royal Infirmary
}

SUMMARY Eight further cases of neurogenic orthostatic hypotension are described together with a necropsy study on one case. Three cases showed evidence of autonomic dysfunction in isolation, while in five cases this was accompanied by evidence of more diffuse central nervous system degeneration. (Parkinsonism, cerebellar ataxia, dementia, pyramidal signs, bulbar weakness, and muscular wasting were all seen in varying proportions.)

The various clinical presentations, investigations, pathology, treatment, and prognosis are discussed. In the experience of the authors, when assessed, an abnormal Valsalva response is invariable, confirming the breakdown of the circulatory reflex. A normal vasopressor response is likewise invariable, eliminating an abnormality of blood vessels themselves, and confirming the lesion as neurogenic. The demonstration of loss of sweating to indirect body heating, which also is usual suggests that the defect is central or on the efferent side of the reflex and a normal pilo-erector response to acetylcholine confirms this as preganglionic. Emphasis is laid on the non-specificity of many accepted physiological tests in this disorder and on the delay in diagnosis consequent upon the variable presentation.

Since Shy and Drager's (1960) report of two patients who had orthostatic hypotension occurring as a prominent feature of a degenerative disease of the nervous system, other similar examples have been reported in the literature. Yet confusion persists about the patterns of neurological involvement which may be associated with postural hypotension and the site of the pathological changes responsible for the latter remains uncertain. In our experience few physicians are aware of the existence of this syndrome so that delay in diagnosis is common. Few cases so far reported have been investigated in any detail and conflicting opinions have been expressed concerning the results of such studies. Several therapeutic regimes have been advocated but as yet few of these methods have been fully evaluated. For these reasons we report here our experience with eight recent cases of centrally determined orthostatic hypotension, including one necropsy study.

\section{MATERIALS AND METHODS}

Eight patients (six males and two females) were studied. Investigations were performed as in-patients and outpatient observation was possible for varying periods from six months to five years. Routine investigations performed on all patients included a full blood count, erythrocyte sedimentation rate, blood urea and electrolytes, blood sugar, blood Wassermann reaction, urine analysis (for protein, porphyrins, sugar, specific gravity, etc.), urinary hydroxy-methoxymandelic acid, electrocardiograph (ECG), chest and skull radiographs, cerebrospinal fluid examination, and adrenal function studies (urinary oxogenic and oxosteroids or Synacthen test).

In six patients arterial cannulation studies were performed using a fine indwelling polyethylene cannula introduced into the brachial artery. Continuous arterial pressure recordings were made and the responses noted to change in posture on table tilt, the Valsalva manoeuvre, external stimuli-for example, sudden noise, mental arithmetic-the cold pressor test, and infusions of angiotensin and intramuscular metaraminol bitartrate.

A standard Valsalva manoeuvre was performedthat is, forced expiration against a closed glottis for seven seconds (Sharpey-Schafer, 1955).

The cold pressor test (Pollock, Bospches, Chor, Finkelman, Arieff, and Brown, 1951) involved immersion of one arm in water at $4^{\circ} \mathrm{C}$ for one minute.

Angiotensin II (Hypertensin-Ciba) was infused at a rate of $0.5-1.0 \mu \mathrm{g} / \mathrm{min}$ until a rise in blood pressure was noted.

Metaraminol bitartrate $(6 \mathrm{mg})$ was injected intramuscularly finally and the response to this noted.

Attempts to produce sweating were made using either a radiant heat cradle $(900 \mathrm{~W})$ for 30 to 60 minutes, or indirect body heating by arm immersion in warm 
water. 'To detect sweating either quinizarin powder (Guttman, 1940) or starch and iodine (Wada, 1950) were used.

In areas of absent sweating an attempt was made to assess the pilo-erector response to intradermal acetylcholine (5 mg).

Other tests performed included the cough response to intravenous lobeline $(6 \mathrm{mg})$ and the response of heart rate to carotid sinus massage and intravenous atropine (1.5 mg).

\section{CASE REPORTS}

CASE 1

H.S., a male patient, aged 56, presented in 1965 with features of Parkinsonism. He complained of unsteadiness when walking, difficulty in rising from a low chair, slow movements, and tremor which influenced his writing. Speech had become slurred and he was aware of a troublesome tendency for his head to drop, suddenly and without warning, though with immediate recovery.

Examination revealed fixity of facial expression, proximal leg weakness with inability to rise from a low chair, slight limb rigidity, and action tremor of the hands. The right pupil was larger than the left, both reacting normally.

Despite treatment with orphenadrine hydrochloride (Disipal) his symptoms worsened until in 1966 he developed enuresis with frequency. He then divulged a six year history of impotence. Cystoscopy and cystometrography revealed a distended atonic bladder. Partial resection of the bladder neck was carried out.

Re-examination in 1967 showed, in addition, a left ptosis, weakness and wasting of the hand muscles, increased tendon reflexes, and equivocal plantar responses. Tone was not disturbed. The tongue showed a curious ridged appearance and he seemed unable to keep it still. After syncopal episodes in the ward postural hypotension was noted, the blood pressure falling from a level of $140 / 90 \mathrm{~mm} \mathrm{Hg}$ supine to $60 / 0 \mathrm{~mm} \mathrm{Hg}$ after standing for two minutes. The patient had noticed no loss of sweating. There was no relevant family history. Routine investigations were all normal.

A sweat test using quinizarin powder and indirect body heating showed sweating only at the root of the neck despite a rise in body temperature of $3^{\circ} \mathrm{F}\left(1 \cdot 7^{\circ} \mathrm{C}\right)$. The patient could not perform Valsalva's manoeuvre but there was no pulse variation with change in posture, external stimuli, or carotid sinus pressure. His blood pressure consistently fell with changes in posture. Syncope, at first infrequent, subsequently became more troublesome, necessitating a further admission in December 1967. The patient then complained of a dry mouth and a weak voice and weakness of the depressors of the left eye was noted.

Treatment with $9 a$ fluorohydrocortisone $0.3 \mathrm{mg} /$ day, combined with elastic stockings and an abdominal binder, enabled him to maintain a standing blood pressure of $110 / 70 \mathrm{~mm} \mathrm{Hg}$ for more than 10 minutes. Unfortunately, he died at home one year later after an illness in which he had vomiting, syncope, dyspnoea, and dysphagia.
POST-MORTEM FINDINGS Gross findings were of severe bronchopneumonia, moderate bilateral hydronephrosiz dilatation and hypertrophy of the ureters, and a large bladder. Prostate enlargement was trivial. The brai weighed $1,150 \mathrm{~g}$ and showed no macroscopic abnormality Naked eye examinations of the spinal cord, dors root ganglia, peripheral nerves, sympathetic gangliad and muscles revealed no abnormality.

HISTOLOGY Cerebral hemispheres and basal ganglif Blocks of tissue from selected areas of the cerebrat cortex and white matter, putamen, globus pallidus, caudate nucleus, thalamus, amygdaloid, and hypo thalamus were embedded in paraffin and $10 \mu$ sections were stained with haematoxylin and eosin $(\mathrm{H}$ and $\mathrm{E}$ ) haematoxylin and Van Giesson (HVG), Nissl and Loyez stain for myelin. Many blocks were also staine $\mathscr{\Phi}^{\circ}$ by Holzer method for astrocytes.

The leptomeninges, the blood vessels and the cortex and white matter from the frontal, temporal, and parietal lobes and the insula and hippocampus showe $\Phi$ no lesions. The putamen showed a pallor in sections stained with $\mathrm{H}$ and $\mathrm{E}$; the neuropil having been trans formed into a finely meshed net. Very few surviving neurones could be identified but astrocytic nuclew were present in excess and often in pairs, some nucle having voluminous eosinophilic cytoplasm. Fine granules of golden brown pigment were present, usually in closse relation to astrocytic nuclei but also encrusting soonth surviving neurones and within microglial cells. Mospop the pigment stained positively for iron with Peg method and was considered to be haemosiderin. (Someof it did not but was birefringent under polarized light and was named formalin haemoglobin pigment.) Wiâte fibre bundles were missing within this lesion, which id

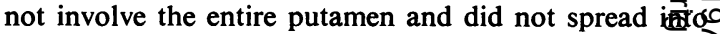
the globus pallidus or caudate nucleus. No lesions were recognized in the amygdaloid nucleus, substriatal grey matter, thalamus, or hypothalamus.

Brain-stem and cerebellum The substantia nigra appeare to have a full complement of neurones excep for a small region in the lateral part of the zona compactad in the lower midbrain where an increase in astrocytes replaced some loss of neurones. Very few microglia cells containing pigment were present and these were widely dispersed throughout the substantia nigra. In addition approximately one fifth of neurones through? out the substantia nigra consisted of a sac of pigments without visible nucleus or had fragmented, the pigment granules lying loose in the neuropil. This widely scattereo neuronal necrosis appeared not to have excited any cellular response and was taken to mean very recent cell death, which may have been agonal.

In the locus caeruleus some cell loss and gliosis was found but no similar change was seen at three levels ing the dorsal vagal nucleus, although no pigmented cells were found. No Lewy bodies or neurofibrillary tangles were found.

No other lesions were recognized in the midbrain of pons. In the medulla oblongata, in sections stained by̆ the Loyez method, the pyramids showed moderate pallor. The cerebellar cortex showed some loss of granulew 
cells attributable to post-mortem autolysis. Purkinje cells were normal. Otherwise no lesions were found in the vermis or cerebellar hemispheres, the dentate or roof nuclei.

Spinal cord The crossed pyramidal tract showed a pallor in Loyez stained sections similar to that of the pyramids. The interomediomedial and interomediolateral columns were examined in all thoracic segments and, although formal counting was not employed, the numbers of cells did not differ from control sections and there was no evidence of gliosis. The parasympathetic column of neurones in the sacral segments also appeared normal.

Peripheral nervous system Specimens obtained of third, fourth, and fifth cervical nerve roots and dorsal root ganglia, brachial plexus, median, sciatic, phrenic, and vagus nerves and sympathetic ganglia were embedded in paraffin and $10 \mu$ sections were stained with $\mathrm{H}$ and $\mathrm{E}$, HVG, solochrome-cyanin, and Holmes's method for axons.

Sections of the fourth, fifth, and sixth cervical anterior and posterior nerve roots showed no abnormality, but the spinal ganglia at these levels showed a few shrunken neurones surrounded by an increased number of satellite cells and a few dense collections of satellite cells without any central remnant of neurones. Sections of the brachial plexus, median nerves, and the phrenic and vagus nerves in the neck showed no abnormality. The inferior ganglion of the vagus was also normal.

Transverse and longitudinal sections of the sciatic nerve showed a mild but definite loss of myelin sheaths and axons, and variable but definite endoneurial thickening.

Sympathetic chain Ganglia of the sympathetic chain showed some loss of neurones with proliferation of satellite cells; all stages were seen from some cell shrinkage with a slight excess of satellite cells to the disappearance of neurones, leaving nests of closely packed satellite nuclei. The endoneurial sheaths of the bundles of both pre- and post-ganglionic fibres were abnormally thickened. The adrenal medulla was autolysed. Parasympathetic ganglia normal in appearance were found in sections of bowel and bladder.

Muscle The biceps brachii and opponens pollicis muscles appeared entirely normal. M. biceps femoris showed slight evidence of disseminated neurcgenic atrophy; a similar process was more marked in the semispinalis capitis, in which many isolated atrophic and angulated fibres were seen lying between groups of morphologically normal fibres ( $\mathrm{H}$ and $\mathrm{E}$ ).

Skin Skin from the right forearm and thenar eminence showed no abnormality on $\mathrm{H}$ and $\mathrm{E}$ stains; in particular the sweat glands appeared entirely normal.

In summary, the positive findings were of putamenal cell loss and gliosis, substantia nigra compacta cell loss and gliosis together with a degenerative process involving pyramidal tracts. Sympathetic ganglion cell loss and fibre thickening was present together with neurogenic atrophy in certain muscles.

SUMMARY Diffuse autonomic involvement accompanied by a 'Parkinsonian' syndrome and early bulbar muscle paresis.

CASE 2

This male patient (S.C.) presented in 1964 at the age of 50 with a four year history of impotence and left-sided anhidrosis, and for two years lightheadedness after walking 20 yards $(18 \mathrm{~m})$ which was relieved by stooping, but on occasions progressed to loss of consciousness. Recently he had developed hesitancy of micturition and constipation.

He was a healthy, well-built man with no abnormal neurological signs and no clinical abnormality other than a dry tongue and postural hypotension. His blood pressure was $110 / 70 \mathrm{~mm} \mathrm{Hg}$ supine and fell to $65 / 40 \mathrm{~mm}$ $\mathrm{Hg}$ after walking 20 yards $(18 \mathrm{~m})$. Routine investigations were normal.

On a table-tilt a blood pressure of $150 / 105 \mathrm{~mm} \mathrm{Hg}$ supine fell to $60 / 40 \mathrm{~mm} \mathrm{Hg}$ in the vertical position with return to resting levels on resuming the horizontal. A sweat test showed sweating was absent from the left side of the trunk and an ECG showed negligible changes in heart rate with exercise and change in posture.

Treatment initially with $9 \alpha$ fluorohydrocortisone 0.2 to $0.3 \mathrm{mg} /$ day produced dramatic improvement, the patient being able to play 18 holes of golf. Gradually, however, postural hypotension returned requiring provision of elastic stockings and an abdominal binder. Since that time the condition has shown considerable day to day variation. If he neglects his drugs and supports for 24 to 48 hours, severe hypotensive symptoms return. There are still no signs outside the autonomic system and since 1965 he has been reluctant to be admitted for further investigations.

SUMMARY A case with no neurological abnormality other than orthostatic hypotension and hemi-anhidrosis.

\section{CASE 3}

This patient (J.W.) presented initially at a surgical clinic in 1966 with a one year history of frequency, enuresis, and impotence. His bladder was distended after micturition (confirmed by intravenous pyelogram which was otherwise normal). Cystoscopy showed a chronically obstructed bladder, apparently due to bladder hypertrophy, and a retropubic prostatectomy with bladder neck resection was performed.

When seen in the Neurological Clinic in August 1968 at the age of 54 years he had the same urinary troubles but now complained of dizziness, faintness on effort, unsteadiness of gait, and was generally slow with a rather weak voice. The family history was negative.

He was a slim man of average height with an expressionless face and slow movements. He walked with a stooped posture and shuffling gait. There was bilateral ptosis, some restriction of ocular convergence, and the right 
pupil was larger than the left, although both reacted normally. His blood pressure fell from $130 / 70 \mathrm{~mm} \mathbf{H g}$ lying to $80 / 50 \mathrm{~mm} \mathrm{Hg}$ on standing. Indirect laryngoscopy showed bilateral adductor paresis of the vocal cords.

Routine investigations were normal.

Using concentric needle electrodes electromyograms were obtained from the right extensor digitorum brevis, abductor digiti minimi, and tibialis anterior muscles, which showed evidence of reduced interference patterns with large polyphasic potentials suggestive of partial denervation. Motor nerve conduction in the right lateral popliteal nerve was slowed at $35 \mathrm{~m} / \mathrm{sec}$ with a terminal latency of $5.3 \mathrm{msec}$ and in the right ulnar nerve somewhat slow at $44 \mathrm{~m} / \mathrm{sec}$ with a terminal latency of $3.8 \mathrm{msec}$.

A sweat test produced slight sweating only on the face and axillae. Arterial cannulation studies with continuous pressure recording showed a defective response to the Valsalva manoeuvre, and there was no response to external stimuli, such as sudden noise and mental arithmetic. The blood pressure rose with the head lowered $30^{\circ}$ and fell from $140 / 80 \mathrm{~mm} \mathrm{Hg}$ to $70 / 50 \mathrm{~mm} \mathrm{Hg}$ on tilting from horizontal to vertical over a period of two minutes. The pulse rate changed insignificantly during the above procedures.

No specific treatment was given, since syncope was not troublesome. More recently he has developed dysphagia.

SUMMARY A case showing autonomic involvement with Parkinsonian features and early paresis of bulbar muscles.

\section{CASE 4}

A.M., a woman aged 75 years presented to us in December 1968 with a 28 year history of syncopal attacks, particularly on standing for long periods; dizziness had been troublesome for 15 years. For most of this time she had nocturia with incontinence despite two operations for stress incontinence. Heat intolerance had been a feature for some years and she claimed never to have sweated below the neck. Immediately before admission she had developed occipital headache and anorexia. There was no significant family history.

Examination showed that the patient was very fit for her age with the exception of postural hypotension, the blood pressure falling from a level when supine of $140 / 70 \mathrm{~mm} \mathrm{Hg}$ to $80 / 50 \mathrm{~mm} \mathrm{Hg}$ on standing. There were no abnormal neurological signs.

Routine investigations were normal.

A sweat test showed complete anhidrosis despite a rise in body temperature of $1.4^{\circ} \mathrm{F}\left(0.8^{\circ} \mathrm{C}\right)$. Arterial pressure recordings from the left brachial artery again showed a defective response to the Valsalva manoeuvre and a marked fall in blood pressure on table-tilt from horizontal to vertical $(150 / 60 \mathrm{~mm} \mathrm{Hg}$ to $50 / 30 \mathrm{~mm} \mathrm{Hg}$ ). The cold pressor test, however, produced a rise in blood pressure of $25 / 10 \mathrm{~mm} \mathrm{Hg}$ and exaggerated pulse changes were present with changes of posture.

Treatment with $9 \alpha$ fluorohydrocortisone $0.3 \mathrm{mg} /$ day, elastic stockings, and an abdominal binder cured her dizziness; blood pressure was maintained at $130 / 90 \mathrm{~mm}$ $\mathrm{Hg}$ when standing and during exercise.
SUMMARY A case of 'pure' orthostatic hypotension $Z_{\mathbb{D}}$ with no other neurological abnormality. There was also total anhidrosis.

\section{CASE 5}

G.T., a 54 year old male patient was referred for investigation of dysarthria which had first become manifesto three years previously, and was followed by progressive unsteadiness of gait. Over the few months before ad mission he had felt faint after standing for more than: a few minutes, and on many occasions had been forced $\overrightarrow{\bar{F}}$ to lie down. Some difficulty in initiating micturition together with frequency and impotence, had been presente for three years and for the previous 20 years he had been aware of lack of sweating.

His father had walked unsteadily and slurred his words for many years before his accidental death when agedn 63 , and his son was said to suffer from fainting spells.

He was a thin, tall (6 ft. 1 in.; $160.6 \mathrm{~cm}$ ) man, the only $\overrightarrow{0}$ abnormality on general examination being a postura ${ }_{-}$ fall in blood pressure from $150 / 90 \mathrm{~mm} \mathrm{Hg}$ to $70 / 40 \vec{\omega}$ $\mathrm{mm} \mathrm{Hg}$. His gait was ataxic, although he was unable to tolerate the upright posture for more than a few minutes without fainting. A slurring dysarthria and bilateral limb ataxia of cerebellar type was evident andw all deep tendon reflexes were increased.

Routine investigations were normal.

Continuous blood pressure recording via an indwellipg brachial artery catheter confirmed the postural fall dur tilting and an abnormal blood pressure response to theValsalva manoeuvre was demonstrated.

The blood pressure response to intravenous angos tensin was normal. However, there was no rise in blood pressure with the stress of sudden noise or menas arithmetic. No increase in pulse rate after intraven ب्ă atropine $(1.5 \mathrm{mg})$ was found, although the response to intramuscular metaraminol bitartrate $(6 \mathrm{mg})$ wasp normal. Intradermal acetylcholine caused piloerection He did not sweat below the neck. An air encephalogranp showed some pontine atrophy and psychometry suggestec5 early intellectual impairment.

Ephedrine, $90 \mathrm{mg}$ t.d.s., a high salt diet, $9 \alpha$ fluoro hydrocortisone, $0.4 \mathrm{mg}$ daily, and tight elastic stockings were only partially successful in alleviating symptoms

An Air Ministry ' $G$ ' suit has enabled the patient to be on his feet for longer periods and he continues to wear this.

SUMMARY Diffuse autonomic involvement accompanyं ing a case suggestive of olivopontocerebellar degenera tion.

\section{CASE 6}

M.1., a 48 year old woman was referred by a psychiatris with a three month history of progressive clumsiness shaking of her hands, and unsteadiness of gait. Over thê same period she had become increasingly asthenie and had noticed profound dizziness on standing.

General examination was unremarkable apart from \& postural fall in blood pressure from $110 / 80 \mathrm{~mm} \mathrm{Hg}$ to 
90/40 mm $\mathrm{Hg}$. Her gait was ataxic and a slurring dysarthria and asymmetrical $(\mathrm{L}>\mathrm{R})$ limb ataxia of cerebellar type were present. At times a static tremor of the left hand was evident and all deep tendon reflexes were increased with extensor plantar responses.

This case was submitted to similar investigations to those performed in case 5 with similar results (see Table 1). Air encephalogram and psychometry were omitted.

Oral ephedrine, $90 \mathrm{mg}$ q.d.s. produced no benefit and partial relief of symptoms has been achieved with $9 \alpha$ fluorohydrocortisone, $0.4 \mathrm{mg}$ daily, a high salt diet, and elastic support stocking tights.

SUMMARY This case showed evidence of autonomic dysfunctional with striatal, cerebellar, and pyramidal involvement.

\section{CASE 7}

F.O.L., a 31 year old male student presented as an emergency with a two week history of increasing tiredness and lethargy and a two day history of nausea, vomiting, and diplopia. Over the following week he became aware of dizziness after rising from bed and at this stage he admitted to increasing frequency and hesitancy of micturition with decreased potency over the preceding six months.

He appeared to be a fit man and apart from equally unreactive pupils (to light or accommodation) the only abnormality found was a postural fall in blood pressure from $130 / 90 \mathrm{~mm} \mathrm{Hg}$ to $50 / 0 \mathrm{~mm} \mathrm{Hg}$. The pupillary reactions returned after two weeks and six months later no further signs had developed.

The routine investigations performed in the other patients were all normal in this case.

Continuous blood pressure monitoring revealed a fall in blood pressure during tilting and the response to the Valsalva manoeuvre was abnormal. This patient showed a positive pressor response to metaraminol bitartrate and angiotensin and a normal response to intradermal acetylcholine. A negative cold pressor test and no response to intravenolis atropine were noted while coughing was induced by intravenous lobeline.

Patchy sweating loss over the trunk and limbs was present. An air encephalogram revealed no abnormality. After treatment with $9 \alpha$ fluorohydrocortisone he was able to resume his studies and nine months later no further signs had developed.

SUMMARY This patient presented acutely with evidence of autonomic dysfunction.

\section{CASE 8}

J.T., a 49 year old Rumanian male, presented in 1969 with a two and a half year history of progressive unsteadiness of gait and dizziness on standing. By the time of admission he was barely able to walk. He had been impotent for the preceding four years but thought his sweating was normal. For a few months before admission he had noticed difficulty in writing and increasing $5^{*}$ tremor picking up objects. The rest of his history was unrevealing.

Examination revealed a postural fall in blood pressure from $160 / 90 \mathrm{~mm} \mathrm{Hg}$ to $100 / 50 \mathrm{~mm} \mathrm{Hg}$. His gait was markedly ataxic and he was unable to stand for more than a few minutes. Bilateral limb ataxia of cerebəllar type was present. The reflexes were normal.

Routine investigations were normal.

Sweat testing revealed patchy loss over the trunk and limbs. Arterial cannulation studies confirmed the postural fall in blood pressure and an abnormal response to the Valsalva manoeuvre.

Responses to intradermal acetylcholine, intramuscular metaraminol bitartrate, intravenous atropine, and angiotensin were normal. Initially treatment was started with ephedrine, $90 \mathrm{mg}$ t.d.s., salt tablets, and $9 \alpha$ fluorohydrocortisone, $0.3 \mathrm{mg}$ daily. On this regime sufficient improvement occurred to enable the patient to walk up to 100 yards. Three months later he remains unchanged.

SUMMARY This patient showed evidence of autonomic dysfunction and cerebellar ataxia.

\section{DISCUSSION}

CLINICAL PRESENTATION These eight cases exemplify the varied patterns of neurological involvement accompanying postural hypotension and illustrate the difficulties encountered in establishing a definitive diagnosis. Most commonly features of associated Parkinsonism or of a cerebellar syndrome will be found. Even when autonomic pathways alone are involved ( $75 \%$ of some series) (Young, 1941; Schatz, Podolsky, and Frame, 1963; Thomas and Schirger, 1963) symptoms and signs may be numerous (Table 2). A banal complaint of impotence or frequency of micturition may lead the unwary to pursue local treatment and overlook the more general implications (case 3). More extensive neurological involvement (Table 3) may overshadow the autonomic disturbance leading to an erroneous diagnosis of Parkinson's disease or hereditary ataxia. We ourselves are at present re-examining all of our cases of progressive degenerative disease of the central nervous system, particularly those with hereditary ataxia, to assess the incidence of autonomic involvement. One of our cases (case 5) gave a history strongly suggesting that his father suffered from neurological disease though not from postural hypotension. This patient presented features of olivopontocerebellar atrophy and it is of interest that other authorsfor example, Johnson, Lee, Oppenheimer, and Spalding (1966), and Bannister, Ardill, and Fentem (1967)-have regarded their patients with idiopathic orthostatic hypotension $(\mathrm{IOH})$ as suffering from this variety of system degeneration. Likewise Lewis 
TABLE 1

INVESTIGATIONS OF AUTONOMIC FUNCTION IN THE CASES OF THE PRESENT SERIES

\begin{tabular}{|c|c|c|c|c|c|c|c|}
\hline $\begin{array}{l}\text { Case } \\
\text { nos. }\end{array}$ & $\operatorname{Sex}$ & Age & $\begin{array}{l}\text { Orthostatic } \\
\text { hypotension }\end{array}$ & $\begin{array}{l}\text { Valsalva } \\
\text { response }\end{array}$ & Sweating & $\begin{array}{l}\text { Vasopressor } \\
\text { response }\end{array}$ & $\begin{array}{l}\text { Piloerector } \\
\text { response }\end{array}$ \\
\hline 1 & $\mathbf{M}$ & 56 & Present & $\begin{array}{l}\text { Not } \\
\text { performed }\end{array}$ & $\begin{array}{l}\text { Absent from } \\
\text { trunk and limbs }\end{array}$ & $\begin{array}{l}\text { Not } \\
\text { performed }\end{array}$ & $\begin{array}{l}\text { Not } \\
\text { performed }\end{array}$ \\
\hline 2 & $\mathbf{M}$ & 50 & Present & $\begin{array}{l}\text { Not } \\
\text { performed }\end{array}$ & Absent $\mathrm{L}$ side & $\begin{array}{l}\text { Not } \\
\text { performed }\end{array}$ & $\begin{array}{l}\text { Not } \\
\text { performed }\end{array}$ \\
\hline 3 & $\mathbf{M}$ & 54 & Present & Abnormal* & $\begin{array}{l}\text { Absent from } \\
\text { trunk and limbs }\end{array}$ & $\begin{array}{l}\text { Not } \\
\text { performed }\end{array}$ & $\begin{array}{l}\text { Not } \\
\text { performed }\end{array}$ \\
\hline 4 & $\mathbf{F}$ & 75 & Present & Abnormal* & $\begin{array}{l}\text { Absent below } \\
\text { face }\end{array}$ & $\begin{array}{l}\text { Not } \\
\text { performed }\end{array}$ & $\begin{array}{l}\text { Not } \\
\text { performed }\end{array}$ \\
\hline 5 & $\mathbf{M}$ & 54 & Present & Abnormal* & Absent below neck & Normalt & Normalł \\
\hline 6 & $\mathbf{F}$ & 48 & Present & Abnormal* & $\begin{array}{l}\text { Patchy reduction } \\
\text { over trunk and } \\
\text { limbs }\end{array}$ & Normal† & Normal + \\
\hline 7 & $\mathbf{M}$ & 31 & Present & Abnormal* & $\begin{array}{l}\text { Patchy reduction } \\
\text { over trunk and } \\
\text { limbs }\end{array}$ & Normal $\dagger$ & Normal + \\
\hline 8 & $\mathbf{M}$ & 49 & Present & Abnormal* & $\begin{array}{l}\text { Patchy reduction } \\
\text { over trunk and } \\
\text { limbs }\end{array}$ & Normalt & Normal + \\
\hline
\end{tabular}

*Blood pressure measured via indwelling brachial artery cannula during Valsalva manoeuvre-no diastolic overshoot with slow rise back to normal.

†Normal rise in blood pressure after both $6 \mathrm{mg}$ metaraminol bitartrate intramuscularly and intravenous infusion of argiotensin (CIBA)

$0.5 \mu \mathrm{g} /$ minute.

†Normal piloerector response to intradermal acetylcholine.

TABLE 2

SIGNS AND SYMPTOMS OF AUTONOMIC INVOLVEMENT IN IDIOPATHIC ORTHOSTATIC HYPOTENSION (FROM PRESENT SERIES AND REPORTED CASES)

$\begin{array}{ll}\text { Orthostatic hypotension } & \begin{array}{l}\text { Decreased or absent sweating } \\ \text { Impotence }\end{array} \\ \text { Sphincter disturbance } & \left\{\begin{array}{l}\text { Syncope } \\ \text { Dizziness } \\ \text { Asthenia } \\ \text { Heat intolerance }\end{array}\right. \\ \text { Pupillary abency, frequency } \\ \text { Her incontinence of } \\ \text { or incturition } \\ \text { miarrhoea or } \\ \text { constipation }\end{array}$

Pupillary abnormalities

Excess lacrimation, salivation, or rhinorrhoea

(1964) has commented on the familial incidence of $\mathrm{IOH}$.

In the great majority of cases with IOH previously reported, the disease process has begun insidiously and has progressed gradually, usually over a period of several years. We would emphasize the relatively acute presentation in our youngest patient (case 7) who developed symptoms and signs of extensive autonomic involvement over a matter of a few weeks; the only similar reported case is that of Barnett and Wagner (1958). Most authorities argue that neurological involvement outside the autonomic nervous system is due to a degenerative process rather than to repeated episodes of cerebral anoxia consequent upop postural hypotension.

It was noted by two of our patients (cases 2 ant 5) that their neurological symptoms fluctuated quite markedly from day to day or even during 24 hour period (see Stead and Ebert, 1941). Attempłs $\overrightarrow{0}$ to correlate this change with blood pressure levets were not convincing. In our small series, males outnumbered females $6: 2$ and this has been the experience of other authors (Thomas and Schirger, 1963, 1968).

INVESTIGATION While there is a formidable list of

\section{TABLE 3}

NEUROLOGICAL SIGNS WHICH MAY BE ASSOCIATED WITH THE SYNDROME OF IDIOPATHIC ORTHOSTATIC HYPOTENSION (FROM PREVIOUSLY PUBLISHED CASES AND PRESENT SERIES)

\begin{tabular}{|c|c|}
\hline $\begin{array}{l}\text { Ocular } \\
\text { Bulbar } \\
\text { Cortical } \\
\text { Pyramidal } \\
\text { Striatal } \\
\text { Cerebellar } \\
\text { Lower motor neurone }\end{array}$ & $\begin{array}{l}\text { Ptosis } \\
\text { External ocular palsies } \\
\text { Dysphagia } \\
\text { Dysphonia } \\
\text { Mental change } \\
\text { Dementia } \\
\text { Hyperreflexia } \\
\text { Extensor plantar responses } \\
\text { Tremor } \\
\text { Rigidity } \\
\text { Bradykinesia-gait, expression, etc. } \\
\text { Dysarthria } \\
\text { Limb and truncal ataxia } \\
\text { Muscle wasting }\end{array}$ \\
\hline
\end{tabular}


medical and neurological disorders which may be complicated by a postural fall in blood pressure (Tables 4 and 5), these are for the most part readily excluded by the history and clinical examination. Routine investigations, though advisable, were in our patients unrevealing.

Siting the lesion within the reflex arc responsible for the maintenance of vascular tone with change of posture requires detailed investigation. Some of the tests used have been available only in recent years and the conflicting results obtained probably result from difficulty in standardization, the small changes observed, and the varying pattern and severity of involvement in individual patients.

Attempts to define orthostatic hypotension by the extent of the postural fall in blood pressure are not satisfactory, as exercise may be necessary to produce hypotension and postural changes may be recorded in normotensive and hypertensive patients (not receiving treatment) without evidence of autonomic or other neurological disease (Fotino and Raiciulescu, 1964; Johnson, Smith, Spalding, and Wollner, 1965). It is the patient's response to the fall in blood pressure which is characteristic, in that the affected individuals experience faintness, dizziness, generalized weakness, and sometimes ataxia and it is important to note that only slight falls in blood pressure may be necessary where the recumbent blood pressure is low. The Valsalva manoeuvre, where attempted, gave uniformly and unequivocally abnormal responses indicating a breakdown in the circulatory reflex; others have not always found this consistency (Martin, Travis, and van der Noort, 1968). Moreover, the increase in heart rate in response to a fall in blood pressure is not usually seen in these patients. The Valsalva manoeuvre does not indicate which segment of the reflex arc is involved. The normal end organ response to intradermal acetylcholine in the face of loss of sweating to radiant heat or indirect body heating and histologically normal sweat glands suggests that the defect is preganglionic (Bárány and Cooper, 1956).

That the arteriolar pressor response is intact can be demonstrated by infusion of a vasoconstrictor agent. Some workers (Hohl, Frame, and Schatz, 1965) have claimed this response to be exaggerated in IOH but confirmation of this requires careful standardization of the infusion and inclusion of controls.

Attempts may be made to test the efferent limb of the circulatory reflex by observing the blood pressure response to mental arithmetic under harassment, unexpected loud noises, and immersion of an arm in ice-cold water. Although in most of our patients these were impaired, this was not

TABLE 4

SOME CAUSES OF SYMPTOMATIC ORTHOSTATIC HYPOTENSION

\begin{tabular}{|c|c|c|c|}
\hline Inadequate cardiac output & $\begin{array}{l}\text { Impaired peripheral } \\
\text { resistance }\end{array}$ & $\begin{array}{l}\text { Reduced effective } \\
\text { blood volume }\end{array}$ & Mixed \\
\hline $\begin{array}{l}\text { Myocardial disease } \\
\text { Valvular heart disease } \\
\text { Pericardial disease } \\
\text { Left atrial myxoma } \\
\text { Ball valve thrombus } \\
\text { Pregnancy }\end{array}$ & $\begin{array}{l}\text { 1. Physiological: } \\
\text { post-febrile illness } \\
\text { post-exercise } \\
\text { space flights etc. } \\
\text { 2. Pathological: } \\
\text { CNS disorders }\end{array}$ & $\begin{array}{l}\text { Shock syndromes } \\
\text { acute } \\
\text { chronic }\end{array}$ & $\begin{array}{l}\text { Addison's disease } \\
\text { Hypopituitarism } \\
\text { Diabetic ketosis } \\
\text { Aldosteronism } \\
\text { Potassium depletion } \\
\text { Amyloidosis } \\
\text { Phaeochromocytoma } \\
\text { Drugs }\end{array}$ \\
\hline
\end{tabular}

TABLE 5

SOME CNS DISORDERS WHICH MAY CAUSE ORTHOSTATIC HYPOTENSION (IDIOPATHIC GROUP EXCLUDED)

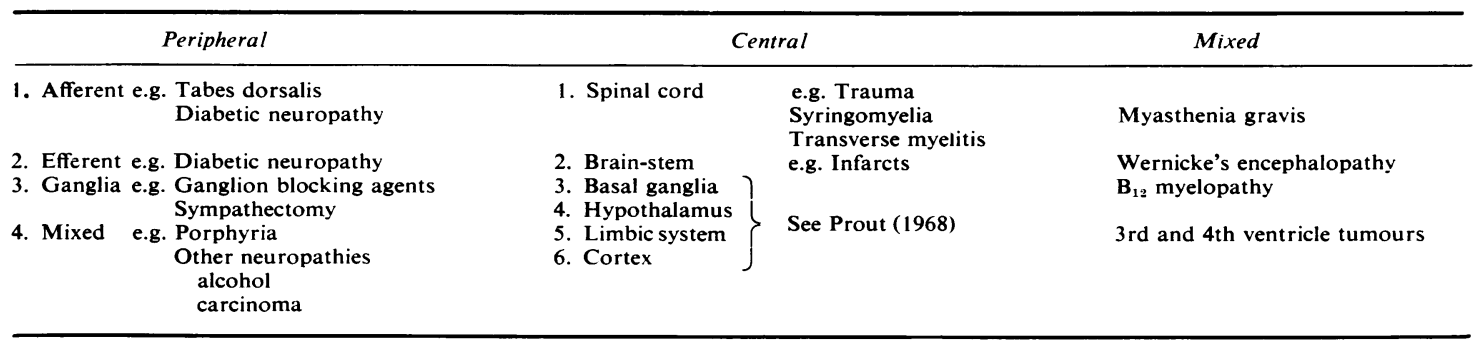


so in all (cases 4 and 5) and even in healthy controls changes were not great. This confusion is reflected in the literature where Martin et al. (1968) note a normal cold pressor response as did Crost and Friedlander (1952), but defective responses were found by Barnett, Hamilton, and Kay (1955), and Page, Hickam, Sieker, McIntosh, and Pryor (1955).

Bannister et al. (1967) were unable to devise a satisfactory test for the afferent segment of the baroregulator pathway. Carotid massage was not in our experience a useful test and hyperventilation or coughing in response to dimethyl-phenylpiperazium (lobeline) tests only afferent pathways in glossopharyngeal and vagus nerves. Martin et al. (1968) regard reflex bradycardia in response to hypertension as a test of afferent integrity. No reflex bradycardia was observed in our patients (cases 5, 6, 7, and 8) where hypertension was induced.

Despite inconsistencies it has been concluded that the defect is centrally placed (Stead and Ebert, 1941 ; Verel, 1951; Martin et al., 1968), accounting also for the anhidrosis, bladder dysfunction, impotence, and pupillary abnormalities. These workers suggest that hypotension may result from defective central autonomic control of aldosterone secretion and renin release. Investigations are in progress to test this hypothesis. For some time there has been interest in the endocrine aspects of this syndrome and there now seems little doubt that there is some disorder not only of cathecholamine production (Hickler, Thompson, Fox, and Hamlin, 1959) but also of the renin-angiotensin system(Slaton and Biglieri, 1967). Further research along these lines would seem indicated not only from the point of view of the therapeutic possibilities, but also because of the physiological implications.

In summary, we suggest that the investigations listed in Table 1 will allow localization of the lesion to the efferent preganglionic segment of the sympathetic circulatory reflex arc and that the further tests we have mentioned do not help either diagnostically or therapeutically.

PATHOLOGY The absence of lateral column degeneration in the thoracic cord of case 1 and the similar negative findings of Martin et al. in their case serve to illustrate that orthostatic hypotension is not explicable in all cases on the basis of intermediolateral column degeneration, however physiologically attractive this may be, although this degeneration has been reported in eight necropsies to date. The findings in the sympathetic ganglia and thickening of the pre- and post-ganglionic endoneurium were a little surprising, particularly in view of the normal sweat glands. However, the lesions were patchy and although their signifi- $\underset{\mathbb{D}}{Z}$ cance is not clear these obviously could not explain $\subseteq$ the whole picture of autonomic dysfunction.

Other features including putamenal cell loss $\underset{0}{\stackrel{\complement}{0}}$ and gliosis, substantia nigra compacta cell loss 7 (compatible with the dopaminergic theory of Parkinsonism), and pyramidal tract demyelination $\stackrel{5}{?}$. have been noted in previous reports, indicating multiple system atrophy. The evidence of de-. nervation atrophy of the semispinalis capitis $\overrightarrow{\vec{B}}$ muscle was an interesting finding in case 1, particularly in view of the weakness of neck muscles which was clinically evident.

MANAGEMENT Treatment of chronic persistent $\stackrel{\mathbb{Q}}{\mathscr{Q}}$ orthostatic hypotension, particularly in those \& cases with other neurological disease, in our ex- $\vec{\circ}$ perience is often difficult. Avoidance of precipitating factors-for example, hot baths, hyperventilation, $\overrightarrow{\vec{\omega}}$ overheating, coughing, sneezing, and strainingalthough theoretically sound, is rarely beneficial in practice and avoidance of the major precipitating? factor-that is, the upright posture-is impractical. $\omega$ Further treatment along three lines should followed: (1) salt retaining steroids and increase dietary sodium; (2) sympathomimetic drugs; arf (3) mechanical aids.

In our experience $9 \alpha$ fluorohydrocortisone $\bar{x}_{\bar{c}} \vec{c}$ combination with a high salt intake will benefit a pro -5 portion of patients and is worthwhile in the initial ${ }^{\infty}$ management. The mechanism by which this comb nation produces its effect is unknown (Shear, 1968). Sympathomimetic drugs were in our hands disappointing and caused unpleasant side-effects. Recourse to mechanical aids will be necessary in most cases with chronic severe orthostatic hypotension. Guttman and Whitteridge (1947) have $\mathbb{D}$ emphasized the importance of the blood supply to the abdominal viscera in change in posture, $\frac{0}{3}$ showing that sympathetic denervation of such vessels is necessary to produce orthostatic hypotension. Supporting aids which do not encompass the abdomen, such as thigh length stockings, are valueless in this condition. We have tried a specially? designed pair of elastic trousers and tailor-made abdominal binders with some success but, although it is cosmetically unappealing, the use of an Air Ministry antigravity suit is undoubtedly the most effective treatment for severe cases.

PROGNOSIS The prognosis in $\mathrm{IOH}$ seems to be related intimately to the presence or absence of $N$ other system degeneration-for example, striatonigral or olivopontocerebellar-as a review of 0 the literature convincingly demonstrates. Most $\omega$ 
patients with combined $\mathrm{IOH}$ and other system involvement die within three to six years. Idiopathic orthostatic hypertension alone with supportive therapy is more benign as evidenced by cases 2 and 4 who are alive and active nine and 28 years respectively after onset of symptoms. (However accidental death may occur as evidenced by case 1 of Johnson et al. (1966), who was found dead wedged in an upright position not wearing his supports.) On the other hand, case 1 is dead (within five years) and cases 3, 5, and 6 are markedly disabled and their disease process continues to progress.

The following physicians gave permission for their patients to be studied; Drs. W. B. Matthews, V. M.. Leveaux, P. Hudgson, and D. A. Shaw, and Drs. M Goldberg, J. Keaney and T. B. Stretton kindly performed the intra-arterial cannulation studies. We wish particularly to thank Dr. D. A. Howells for the post-mortem and extensive histological studies. The Tables were prepared by the Graphics Department of Newcastle University Medical School and invaluable secretarial assistance was rendered by Mrs. Y. Chisholm, Mrs. C. Swaddle, and Mrs. M. A. Greig.

\section{REFERENCES}

Bannister, R., Ardill, L., and Fentem, P. (1967). Defective autonomic control of blood vessels in idiopathic orthostatic hypotension. Brain, 90, 725-746.

Bárány, F. R., and Cooper, E. H. (1956). Pilomotor and sudomotor innervation in diabetes. Clin. Sci., 15, 533-540.

Barnett, A. J., and Wagner, G. R. (1958). Severe orthostatic hypotension: case report and description of response to sympatheticomimetic drugs. Amer. Heart. J., 56, 412-424.

Barnett, A. J., Hamilton, M. D., and Kay, H. B. (1955). Severe orthostatic hypotension. Aust. Ann. Med., 4, 183-194.

Crost, A. E., and Friedlander, H. (1952). Orthostatic hypotension: report of a case refractory to vasoconstrictor drugs; with observations on use of desoxycorticosterone, 1-norepinephrine, ACTH and vasopressor potentiating substances. Ann. intern. Med., 36, 1343-1350.

Fotino, S., and Raiciulescu, N. (1964). Defective orthostatic regulation of blood-pressure in essential hypertension. Lancet, 1 , 1182-1185.

Guttman, L. (1940). Topographic studies of disturbances of sweat secretion after complete lesions of peripheral nerves. J. Neurol. Psychiat., 3, 197-210.

Guttman, L., and Whitteridge, D. (1947). Effects of bladder distension on autonomic mechanisms after spinal cord injuries. Brain, $70,361-404$.
Hickler, R. B. Thompson, G. R., Fox, L. M., and Hamlin, J. T (1959). Successful treatment of orthostatic hypotension with 9-alpha-fluorohydrocortisone. New. Engl. J. Med., 261, 788-791.

Hohl, R. D., Frame, B., and Schatz, I. J. (1965). The Shy-Drager variant of idiopathic orthostatic hypotension. Amer. J. Med., 39, 134-141.

Johnson, R. H., Lee, G. de J., Oppenheimer, D. R., and Spalding, J. M. K. (1966). Autonomic failure with orthostatic hypotension due to interomediolateral column degeneration. A report of two cases with autopsies. Quart. J. Med., 35, 276292.

Johnson, R. H., Smith, A. C., Spalding, J. M. K., and Wollner, L. (1965). Effect of posture on blood-pressure in elderly patients. Lancet, 1, 731-733.

Lewis, P. (1964). Familial orthostatic hypotension. Brain, 87, 719-728.

Martin, J. B., Travis, R. H., and van der Noort, S. (1968). Centrally mediated orthostatic hypotension. Arch. Neurol. (Chic.), 19, 163-173.

Page, E. B., Hickam, J. B., Sieker, H. D., McIntosh, H. D., and Pryor, W. W. (1955). Reflex venomotor activity in normal persons and in patients with postural hypotension. Circulation, 11, 262-270.

Pollock, L. J., Boshes, B., Chor, H., Finkelman, I., A rieff, A. J., and Brown, M. (1951). Defects in regulatory mechanisms of autonomic function in injuries to the spinal cord. J. Neurophysiol., 14, 85-93.

Prout, B. J. (1968). Postural hypotension. Hosp. Med., 1, 1269-1276.

Schatz, I. J., Podolsky, S., and Frame, B. (1963). Idiopathic orthostatic hypotension. Diagnosis and treatment. J. Amer. med. Ass., 186, 537-540.

Sharpey-Schafer, L. P. (1955). Effect of Valsalva's manoeuvre on normal and failing circulation. Brit. med. J., I, 693-695.

Shear, L. (1968). Orthostatic hypotension. Treatment with sodium chloride and sodium retaining steroid hormones. Arch. int. Med., 122, 467-471

Shy, G. M., and Drager, G. A. (1960). A neurological syndrome associated with orthostatic hypotension. A clinical-pathologic study. Arch. Neurol. (Chic.), 2, 511-527.

Slaton, P. E., jun., and Biglieri, G. G. (1967). Reduced aldosterone excretion in patients with autonomic insufficiency. J. clin. Endocrin., 27, 37-45.

Stead, E. A., jun., and Ebert, R. V. (1941). Postural hypotension: A disease of the sympathetic nervous system. Arch. intern. Med., 67, 546-562.

Thomas, J. E., and Schirger, A. (1963). Neurologic manifestations in idiopathic orthostatic hypotension. Arch. Neurol. (Chic.), 8, 204-208

Thomas, J. E., and Schirger, A. (1968). Orthostatic hypotension: etiologic considerations, diagnosis and treatment. Med. Clin. N. Amer., 52, 809-816.

Verel, D. (1951). Postural hypotension: the localisation of the lesion. Brit. heart J., 13, 61-67.

Wada, M. (1950). Sudorific action of adrenalin on the human sweat glands and determination of their excitability. Science, 111, 376-377.

Young, R. H. (1941). Association of postural hypotension with sympathetic nervous system dysfunction. Case report, with review of neurologic features associated with postural hyp(stension. Ann. intern. Med., 15,910-916. 